\title{
Inbreeding effects of queen and workers on colony traits in the honey bee
}

\author{
K. Bienefeld, F. Reinhardt and F. Pirchner
}

Lehrstuhl für Tierzucht der Technischen Universität München, 8050 Freising-Weihenstephan, FRG

(received 24 October 1988, accepted 3 July 1989)

\begin{abstract}
Summary - Inbreeding coefficients of queens and workers of 5581 controlled mated colonies were estimated. During a period of over 30 years inbreeding increased by $0.15 \%$ in queens and $0.06 \%$ in workers per year. The highest inbreeding coefficients were $44 \%$ in individual queens and $45 \%$ in individual worker groups, respectively. Using partial regression, the importance and consequences of inbreeding on colony traits were ascertained. Inbreeding seems to affect the two castes differently. Colony performance with regard to honey and wax is significantly depressed $(-6 \%$ and $-8 \%$, respectively, per $1 \%$ inbreeding) by the inbreeding of the workers. In our material, inbreeding of queens did not affect colony efficiency except when workers were also inbred. Workers can compensate for inbreeding depression of queens, but the reverse is not true. Inbreeding of workers leads to calmer and less aggressive colony behaviour, whereas inbreeding of queens has the opposite effect. Swarming tendency increased with increased inbreeding of workers. In contrast, queens with moderate inbreeding have colonies with the highest swarming tendency. Honey production, calmness during examination and swarming tendency show significant interactions between the inbreeding level of queens and workers.
\end{abstract}

\section{Apls mellifera - inbreeding - honey production — aggressiveness - swarming tendency}

\section{INTRODUCTION}

Inbreeding is a powerful tool for creating genetic diversity but it depresses performance, particularly in components of reproductive fitness including fertility, viability and production traits (Dickerson, 1973). In the honeybee inbreeding depression was found both in workers (Brückner, 1975, 1980; Khischa, 1976; Kepena, 1976) and in queens (Hoopingarner and Farrar, 1959; Khischa, 1976; Moritz, 1982) for various traits. This explains the poorer efficiency (Plass, 1953;
Cale and Gowen, 1956; Khischa, 1976) and altered colony behaviour (Plass, 1953).

However, these experiments give no information about the relative importance of inbreeding in queen and workers to colony traits, which are assumed to be affected by both castes simultaneously (Chevalet and Cornuet, 1982). In the present study a method is described for computing the inbreeding coefficients $(F)$ in large sets of colonies with respect to characteristics in reproduction, under controlled mating conditions. Computing $F$ for queens and workers of each colony 
and relating them to recorded colony traits permits the separation of inbreeding effects of the two castes.

\section{MATERIALS AND METHODS}

The study is based on data collected from approved beekeepers organized in two bee breeding societies in Lower Saxony (F.R.G.) and a bee breeding society in Hamburg (F.R.G.). In addition to the results from "stud-books" from beekeepers $(n=96)$, the Research Institutes for Bee Breeding in Celle (Lower Saxony, F.R.G.), Kirchhain (Hessia, F.R.G.) and Lunz (Austria) provided data from their testing stations. The performance tests by beekeepers and the Bee Research Institutes were carried out in the same manner without essential modifications during the period analysed. The honey yield was taken as weight difference of combs before and after extracting honey plus an estimate of honey left in the broodnest. Wax production was estimated by the number of honey and/or drone combs times a factor between 0.06 and 0.07 (depending on comb size). Aggressiveness (defensive behaviour - from very gentle to vicious), calmness during examination (running of the bees during examination), spring development (time when the super had to be given to the colony) and swarming tendency (occurrence of swarming symptoms and reaction of the colony to means of preventing swarming) were scored subjectively. The scoring system ranged from 4 (very good) to 1 (very bad). Intermediate marks (for example, 2.5) were possible (Table I).

For details of the performance test the reader is referred to the paper by Ruttner (1972). The organisation of the breeding scheme has been described by Tiesler (1988). Only colonies $(n=5581)$ from controlled matings or artificial in semination were used in the analyses. The mating stations are located on islands along the North German coast. All are sufficiently far away from the mainland and from each other to maintain complete isolation from unwanted drones. At these "island mating stations" an average of 6 (varying from 4 to 10) colonies with sister queens (queens descended from one dam, who were also mated at an island mating station) provided the breeding drones.

\section{Genetic relationship within and between colonies without Inbreeding}

The genetic relationship (a) between two individuals can be calculated as follows (Malécot, 1948).

$$
a=\left(\Phi+\Phi^{\prime}\right) / 2
$$

where $\Phi=$ probability of identity of maternal genes in 2 animals; $\Phi^{\prime}=$ probability of identity of paternal genes in 2 animals.

Two randomily chosen females (queens or workers; because of the large number of workers per colony the genetic relationship between 2 worker offspring groups of different colonies is

Table I. Measured colony traits.

\begin{tabular}{llccccc}
\hline \multicolumn{1}{c}{ Traits } & Unit & $n$ & $x$ & $s$ & Min & Max \\
\hline & & & & & & \\
Honey & $(\mathrm{kg})$ & 5342 & 24.1 & 13.9 & 0.0 & 99.8 \\
Wax & $(\mathrm{kg})$ & 1724 & 0.86 & 0.33 & 0.0 & 2.0 \\
Aggressiveness & $(\mathrm{P})$ & 2770 & 3.73 & 0.63 & 1.0 & 4.0 \\
Calmness & (P) & 2764 & 3.72 & 0.54 & 1.0 & 4.0 \\
Spring develop. & (P) & 2177 & 3.42 & 0.69 & 1.0 & 4.0 \\
Swarming tendency & (P) & 1534 & 3.50 & 0.69 & 1.0 & 4.0 \\
& & & & & & \\
\hline
\end{tabular}

$P$ : Scored subjectively from 1 (worst) to 4 (best). 
equivalent to the genetic relationship between 2 randomly chosen individual workers from these 2 colonies) from 1 colony have the same dam ( $\Phi=0.5$ ) but because of the multiple mating of their dam, possibly different paternal descent. Therefore at the island mating stations three values for $\Phi^{\prime}$ are possible. The probability $\left(P_{i}\right)$ of the three possibilities depends on the number of drones per queen $(D)$ and the number of droneproducing queens $(S)$ at the island mating stations.

Possibility 1: Descent from the same drone (= same gamete)

$$
\Phi_{1}^{\prime}=1, P_{1}=1 / D
$$

Possibility 2: Descent from different drones of the same drones-producing queen (= different gametes of the same sire, Polhemus et al., 1950)

$$
\Phi_{2}^{\prime}=0.5 ; P_{2}=(1-1 / D) \cdot 1 / S
$$

Possibility 3: Descent from different drones, which come from different but related (a[s]) drone-producing queens

$$
\Phi_{3}{ }^{\prime}=a(s) / 2 ; P_{3}=(1-1 / D) \cdot(1-1 / S)
$$

The average probability of identity of paternal genes $\left(\Phi^{\prime}\right)$ gives

$$
\begin{aligned}
& \Phi^{\prime}=\Sigma \Phi_{1}^{\prime} \cdot P_{1} \\
& =1 \cdot \frac{1}{D}+\frac{1}{2}\left[\left(1-\frac{1}{D}\right) \cdot \frac{1}{s}\right]+\frac{a(s)}{2}\left[\begin{array}{cc}
1 & 1 \\
D & (1--) \cdot\left(1-\frac{-}{S}\right.
\end{array}\right]
\end{aligned}
$$

The genetic relationship between the droneproducing queens is on average the same as the relationship to be estimated.

$$
a=a(s)
$$

Since

$$
\begin{gathered}
a(s) / 2=\left(0.5+\Phi^{\prime}(s)\right) / 4 \text { and } \\
\Phi^{\prime}=\Phi^{\prime}(s)
\end{gathered}
$$

$\Phi$ ' can be expressed as follows

$$
\begin{aligned}
& \Phi^{\prime}=\frac{1}{D}+\frac{1}{2}\left[\begin{array}{cc}
1 & 1 \\
\left(1-\frac{-1}{D} \cdot \frac{-}{S}\right.
\end{array}\right]+\frac{1}{8}\left[\begin{array}{cc}
1 & 1 \\
(1--) & -(1--) \\
D & S
\end{array}\right] \\
& +\frac{1}{4} \Phi^{\prime}\left[\begin{array}{cc}
1 & 1 \\
\left(1-\frac{1}{D}\right) \cdot\left(1-\frac{-}{S}\right. & S
\end{array}\right]
\end{aligned}
$$
to

Which reduces, after some rearrangements,

$$
\Phi^{\prime}=\frac{7 S+3 D+D S-3}{2(S+D+3 D S-1)}
$$

In order to compute the average genetic relationship between two females from different colonies but identical paternal descent $\left(a^{*}\right)$, possibility 1 (same drone) has to be excluded, because drones only mate once. Therefore $\Phi^{*}$ results as follows

$$
\Phi^{\prime *}=\frac{1}{-} \cdot \frac{1}{2} \quad s \quad+\left[\begin{array}{cc}
s-1 & a(s) \\
s & --- \\
2
\end{array}\right] \text { (9) }
$$

Like (7) eq. (9) included only the variables $D$ and $S$ so (9) can also be expressed as a function of these variables.

$$
\Phi^{\prime *}=\frac{2 S+3 D+D S-2}{2(S+D+3 D S-1)}
$$

Substitution of $D=8$ (Laidlaw, 1974; Woyke, 1985 ) and $S=6$ (notes from the bee breeding societies in Lower Saxony) in eqs. (9) and (10) gives

$$
\begin{gathered}
\Phi^{\prime}=\begin{array}{c}
0.3535 ; a=0.42675 \\
\text { (within colonies) }
\end{array} \\
\Phi^{\prime *}=0.2611 ; a{ }^{*}=0.13057 \\
\text { (between colonies) }
\end{gathered}
$$

\section{Computation of the coefficients of in- breeding ( $F)$}

Heijden et al. (1977) and Dempfle (1987) derived efficient methods to compute the numerator relationship matrix (NRM) for large sets of animals

$$
\mathrm{NRM}=M \cdot D \cdot M^{\prime}
$$

For our purposes only the diagonal elements $1+$ $F_{i}$ (Henderson, 1976) of the NRM have to be calculated. $F_{i}$ is the coefficient of inbreeding of animal $i$ (queen or an "average worker"). The computing technique has been fully described by Bienefeld (1988a). $M$ is a triangular matrix containing only unity in the diagonal and, in the case of animal $i$ (row $i$ ),

$$
0.5 \cdot\left(j \text { th row }+k^{\text {th }} \text { row }\right)
$$

in the off diagonals. Animal $j$ and $k$ are the parents of $i$. The elements of the diagonal matrix D are the theoretical variances of the deviation of the breeding values of the individuals from the true full sib means. These depend on the information available : 


\begin{tabular}{lc}
\hline Possibility & Value $D$ \\
\hline $\begin{array}{l}\text { neither parent known } \\
\text { sire }(\mathrm{s}) \text { or dam (D) known } \\
\text { both parents known }\end{array}$ & $\begin{array}{c}1 \\
\end{array}$ \\
\hline
\end{tabular}

where $F_{S}$ and $F_{D}$ are the coefficients of inbreeding of the parents, which have to be calculated (and stored) first.

This method does not fit the characteristics of reproduction of the honey bee, because the paternal descent cannot be ascribed to a single diploid sire, but only to a mixture of gametes from related sires (sister queens). That means that the theoretical covariance (a) between related individuals is changed compared to normal diploids. Considering eqs. (11) and (12), the following values can be derived.

Considering these deviations in the corresponding off-diagonal elements in $D$ correct computation of the coefficient of inbreeding in the honey bee is possible. However, the accuracy of the computation of the genetic relationship and the coefficient of inbreeding depends on the agreement between assumptions $(D=8$ and $S=6$ respectively) and reality. But variation of these variables in a realistic range ( $S$ from 4 to 9 and $D$ from 5 to 11) does not result in any serious deviation from the standard situation (Bienefeld, 1988a).

The method is also suitable for large sets of colonies, but the dimension of the matrices is twice the number of colonies because the inbreeding coefficient of the queen and the "average worker" of each colony has to be computed.

\section{Inbreeding effects}

The statistical model used to quantify the inbreeding effects of queen and workers was

Model I

$$
Y_{i j \mathrm{k}}=u+Y_{\mathrm{i}}+B_{\mathrm{j}}+b^{Q} F^{\mathrm{Q}}+b^{\mathrm{w}} F \mathrm{w}+e_{\mathrm{jk}}
$$

where $Y_{i j k}=$ colony trait of the $k^{\text {th }}$ colony with coefficient of inbreeding $(\mathrm{FQ})$ of the queen and coefficient of inbreeding $(\mathrm{Fw})$ of workers, measured in the $\mathrm{i}^{\text {th }}$ year by the $\mathrm{j}^{\text {th }}$ beekeeper; $u=$ population mean; $Y i=$ effect of the $i^{\text {th }}$ year $(i=$ $1-35) ; B_{i}=$ effect of the $\mu^{\mathrm{h}}$ beekeeper $(j=1-96)$; $F Q=$ coefficient of inbreeding of the queen $10 \%-$ $44 \%$ ) of the $k^{\text {th }}$ colony; $F w=$ coefficient of inbreeding of the workers $(0 \%-45 \%)$ of the $k^{\text {th }}$ colony; $b O=$ partial coefficient of regression of the colony trait on the level of inbreeding of the queen; $b^{w}=$ partial coefficient of regression of the colony trait on the level of inbreeding of the workers; $e_{\mathrm{ijk}}=$ random residual error.

By applyng the following model, interactions between the inbreeding level of queen and workers within colonies can be isolated

$$
\begin{aligned}
& \text { Model II } \\
& Y_{i j \mid m k}=U+T_{i}+B_{j}+F L O_{m}+F L w_{1}+F L O w_{m l}+ \\
& e_{i j m l k} \\
& \text { where } Y_{Y_{j m l k}}=\text { colony trait of the } k^{\text {th }} \text { colony with }
\end{aligned}
$$
$e_{i j m l k}$ a combination of inbreeding level $m$ of the

\section{Relationship Diploids Honeybee Deviation}
a) Full sibs *
0.5
0.42675
$-0.07325$
b) Paternal half sibs **
0.25
0.13057
$-0.11543$
c) Maternal half sibs ***
0.25

* Individuals from the same colony with the same paternal descent.

* Individuals from different colonies, but same paternal descent.

*** Not possible under controlled mating conditions since no second mating at another station is possible. 
queen and level $/$ of workers, measured in the ith year by the $\mathrm{fth}^{\mathrm{h}}$ beekeeper; $F_{\mathrm{i}}, B_{\mathrm{i}}=$ as in model $\mathrm{i}$; $F L Q_{m}=$ effect of the $m^{\text {th }}$ inbreeding level of the queen $(m=1-5)$; $F L w_{1}=$ effect of the lth inbreeding level of the workers $(k=1-5) ; F L q w_{m l}=$ effect of the interaction between the level of inbreeding of the queen $(m)$ and worker $(l)$; $e_{\mathrm{jjmlk}}=$ random residual error.

The inbreeding levels were divided as follows :

\section{Level Percentage of inbreeding}

\begin{tabular}{cc}
\hline 1 & $0 \%$ \\
2 & $0<-<6.25 \%$ \\
3 & $6.25 \%<-<12.50 \%$ \\
4 & $12.50 \%<-<18.75 \%$ \\
5 & $>18.75 \%$ \\
\hline
\end{tabular}

Some beekeepers run the performance testing at different locations within a year. The individual locations within a year and a beekeeper were neglected because colonies sharing the same location also had similar levels of inbreeding. By including the specific location in the model part of the inbreeding, effects are confounded with location effects, causing an underestimate of the inbreeding effects. The results with and without considering the location are quite similar, differing only in the level of significance (Bienefeld, 1988a).

The subjectively judged behaviour and development traits were not normally distributed. For that reason calculation for these variables was done with e(variable) transformed values.

\section{RESULTS}

Figure 1 presents the development of average inbreeding in both castes. The yearly increase of an average of $0.15 \%$ in queens and of $0.06 \%$ in workers is not linear, but is characterized by ups and downs of the level of inbreeding. The level, never exceed- ing $5 \%$, is relatively low. The highest individual inbreeding coefficient was $44 \%$ in queens and $45 \%$ in workers.

All colony traits recorded in Table II are significantly influenced by the year and by the beekeeper. Honey and wax production of a colony is significantly reduced by inbreeding of the worker $(140 \mathrm{~g}$ honey/ percent inbreeding, $7 \mathrm{~g}$ wax/percent inbreeding), whereas the inbreeding of the queen does not influence these colony traits (Table II).

Inbred workers are significantly less agressive and show more calmness during examination. Inbreeding of the queen has a significant effect on calmness during examination, but in the opposite direction. Spring development is not significantly influenced by inbreeding of the two castes.

Swarming tendency increases (a negative sign indicates a poorer classification, i.e. greater swarming tendency) significantly in workers as a result of inbreeding (Table II).

Honey production, calmness during examination and swarming tendency show significant interactions between the inbreeding levels of queen and workers (Table III). By considering this interaction in the model, the inbreeding effect of queens

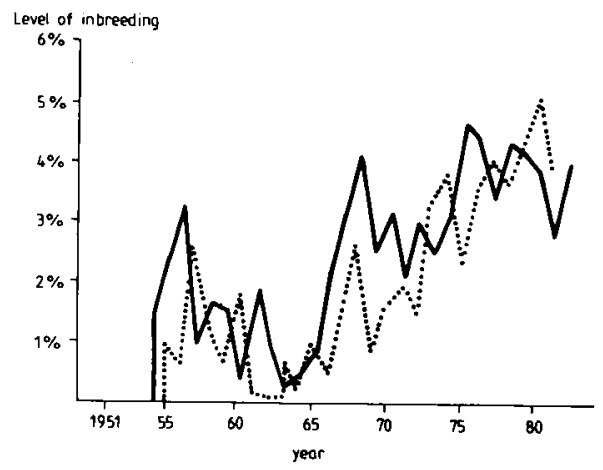

Fig. 1. Level of inbreeding of queens (.....) and workers (-) from 1951-1984. 
Table Il. Effect of inbreeding of queens and workers on colony traits (Model I).

\begin{tabular}{|c|c|c|c|c|}
\hline \multirow{3}{*}{$\begin{array}{c}\text { Colony } \\
\text { trait }\end{array}$} & \multicolumn{2}{|c|}{ F value } & & \\
\hline & \multicolumn{2}{|c|}{$\begin{array}{c}\text { Environmental } \\
\text { effects }\end{array}$} & \multicolumn{2}{|c|}{$\begin{array}{c}\text { Partial } \\
\text { regressions }\end{array}$} \\
\hline & Breeder & Year & Queen & Workers \\
\hline Honey & $44.3^{\star * *}$ & $16.1^{* * *}$ & 0.058 & $-0.141^{* *}$ \\
\hline Wax & $11.0^{\star \star *}$ & $14.1^{\star \star \star}$ & 0.000 & $-0.007^{\hbar * \star}$ \\
\hline Aggressiveness & $3.6^{* * *}$ & $15.7^{* * *}$ & -0.104 & 0.250 \\
\hline Calmness & $5.9^{\star \star \star}$ & $22.6^{\star * *}$ & $-0.245^{* * *}$ & $0.257^{* * *}$ \\
\hline Spring develop. & $3.9^{\star \star \star}$ & $7.9^{\star \star \star}$ & -0.001 & 0.016 \\
\hline Swarming tendency & $3.5^{\star * *}$ & $9.5^{* * *}$ & -0.043 & $-0.500^{* *}$ \\
\hline
\end{tabular}

* : significant at $P<0.05$

** : significant at $P<0.01$

*** : significant at $P<0.001$.

Table III. Effect of inbreeding of queens and workers on colony traits (Model II).

F values

\begin{tabular}{|c|c|c|c|c|c|}
\hline \multirow[t]{2}{*}{$\begin{array}{c}\text { Colony } \\
\text { trait }\end{array}$} & \multicolumn{2}{|c|}{$\begin{array}{c}\text { Environmental } \\
\text { effect }\end{array}$} & \multicolumn{3}{|c|}{$\begin{array}{l}\text { Inbreeding } \\
\text { levels }\end{array}$} \\
\hline & Breeder & Year & $Q$ & $w$ & $Q \times W$ \\
\hline Honey & $15.3^{* * *}$ & $43.0^{* * * *}$ & $3.4^{\star *}$ & $12.2^{* \star *}$ & $3.2^{\star \star \star *}$ \\
\hline Wax & $12.9^{* * *}$ & $10.4^{* * *}$ & 0.7 & 2.0 & 1.2 \\
\hline Aggressiveness & $3.7^{* * *}$ & $13.6^{* * *}$ & 1.9 & 2.2 & 1.5 \\
\hline Calmness & $5.7^{\star \star \star}$ & $19.9^{* * *}$ & $3.6^{*}$ & $4.5^{* *}$ & $2.2^{\star}$ \\
\hline Spring develop. & $4.1^{\star \star \star \star}$ & $7.7^{\star * *}$ & 0.5 & 1.2 & 1.6 \\
\hline Swarming tendency & $3.3^{* * *}$ & $9.3^{* * \star}$ & $12.4^{* * *}$ & $5.2^{\star \star \star \star}$ & $2.6^{*}$ \\
\hline
\end{tabular}

$Q:$ Queen $W:$ Workers

$Q \times W:$ Interactions Queen $\cdot$ Workers

* : significant at $P<0.05$

** : significant at $P<0.01$

*** : significant at $P<0.001$ 
on honey production and swarming tendency also becomes significant. As shown in Fig. 2 for honey production, the impact of inbreeding of queens is most conspicuous when the workers of a colony are also highly inbred. The LSQ-means (Figs. 3 and 4) of the other colony traits show no clear tendency. For calmness during ex- amination, the means indicate (as in Table II) opposite inbreeding effects of queen and workers.

For swarming tendency, a medium inbreeding level of the queen is poorest, whereas the swarming tendency in workers increases more or less with increasing inbreeding level.

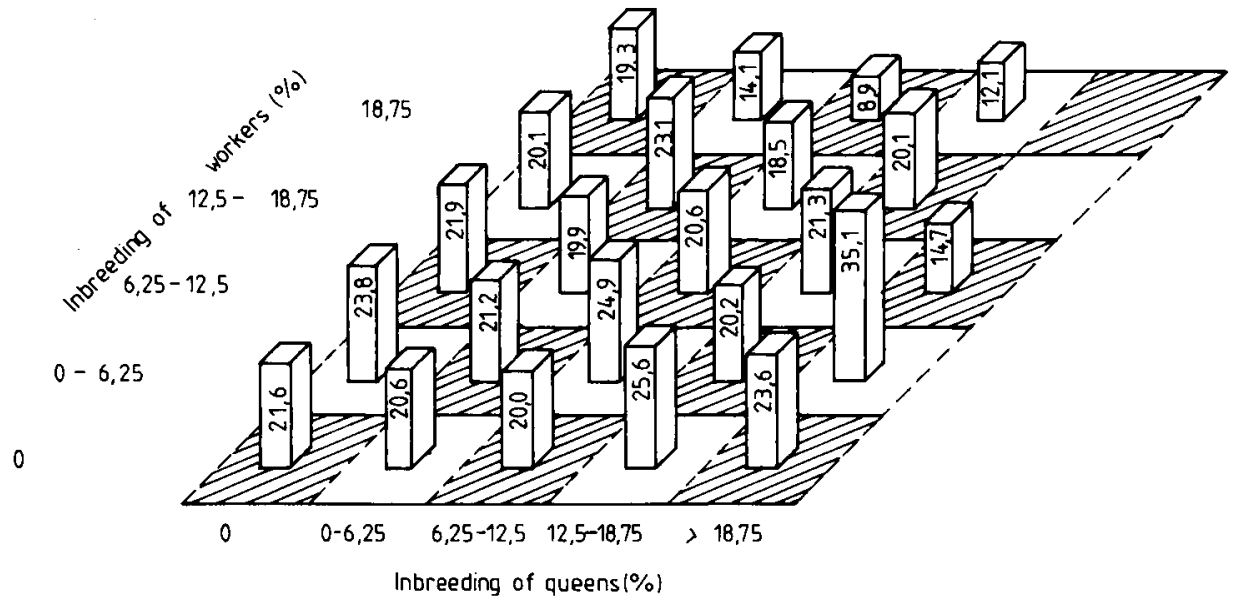

Fig. 2. LS-means for honey production.

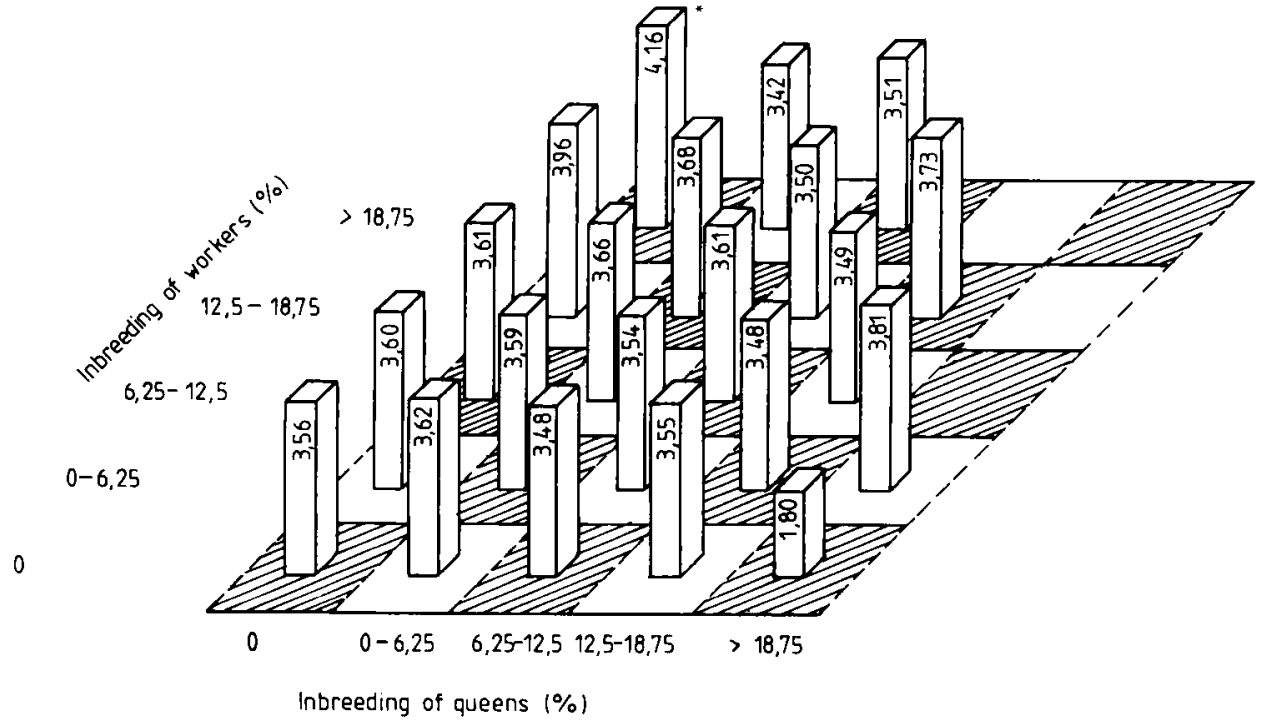

Fig. 3. LS-means for calmness during examination.

*Exceeds the range (1-4) due to correction for environmental effects. 


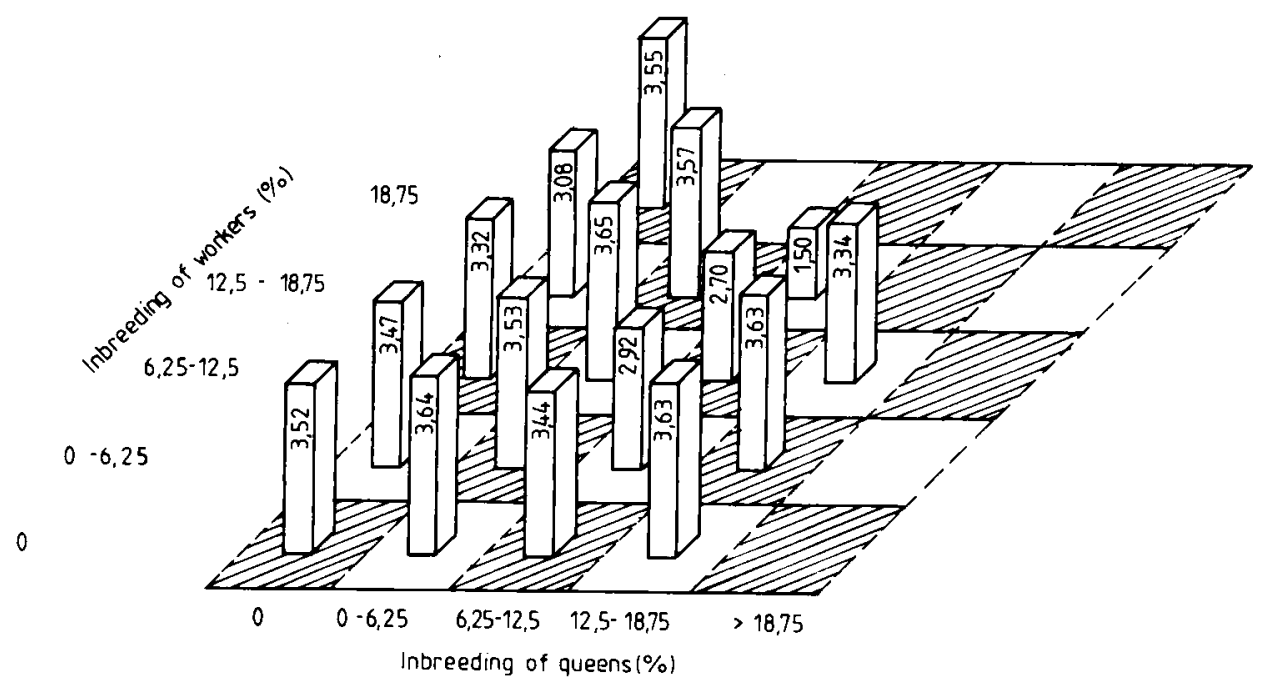

Fig. 4. LS-means for swarming tendency.

\section{DISCUSSION}

Both the development of inbreeding, as given in Fig. 1, and the relatively low level of inbreeding are typical for an "open population". In addition to imports of foreign queens, the beekeepers tried to limit inbreeding depression by "intra-family selection" and by occasionally sending virgin queens to island mating stations with nonrelated (with respect to the young queens) drone-producing queens (Bienefeld, 1988b).

The justifications for these breeding strategies are shown in Table II and Fig. 2. Inbred colonies produce less honey and wax, but it is important to note that this loss of efficiency is mainly caused by inbreeding of the workers. This influences the colony performance in two ways. First by less efficient (Brückner, 1975, 1980) and morphologically handicapped workers (Khischa, 1976; Roberts, 1961); secondly by the mode of sex determination. The higher the level of inbreeding the higher the probability of homozygosity at the sex locus, which causes brood losses (Woyke, 1963).

Similar to our results, Plass (1953) found that colonies in which inbred queens headed non-inbred workers were comparable to normal colonies with respect to brood rearing. Inbreeding depression was only observed in the reverse situation (inbred workers, non-inbred queens).

Surprisingly, the inbreeding of queens does not affect honey performance. Khischa (1976) reported fewer and lighter ovarioles in inbred queens, which may reduce their laying capacity. Cale and Gowen (1956) observed poorer honey production of colonies with inbred, but freely mated, queens (so workers were heterozygotes). But contrary to our situation, Cale and Gowen tested very highly inbred queens $(F=55 \%-66 \%)$ under about 5 times more favourable honey flow conditions. Under this situation the laying capacity of 
queens can be a limiting factor. Under unstable honeyflow conditions and a moderate inbreeding level of queens, non-inbred workers can compensate inbreeding depression of their dam, but queens cannot compensate inbreeding of their workers. Inbreeding of queens only leads to a reduction of performance if the workers of their colony are also inbred (Fig. 2).

Plass (1953) reported decreasing aggressiveness in inbred colonies. We found this tendency (lower aggressiveness, more calmness during examinations) only due to inbreeding of workers. The effect of inbreeding in queens was the reverse. Moritz (1986) observed a depression in physiological and metabolic reactions in inbred workers. Collins et al. (1987) reported, by comparing European and Africanized geographical types of honey bees, genetic differences with respect to defensive behaviour. They speculated that the different behaviour is caused by a greater responsiveness to alarm pheromones. If the threshold of response to the alarm pheromones is determined genetically, this threshold may be sensitive to inbreeding.

Queen pheromones are known to stabilize behaviour in honey bee colonies (Velthuis, 1977; Crewe, 1982). Hoffmann (1961) found queenless colonies more restless and aggressive. It is likely that, in addition to morphological defects (Hoopingarner and Farrar, 1959; Khischa, 1976), the pheromone output of inbred queens is reduced, causing a more irritable behaviour of their workers.

Plass (1953) reported a lower swarming tendency but a considerably higher frequency of supersedure in his highly inbred colonies. Contrary to this findings, we found an increasing swarming tendency due to inbreeding of workers. Considering the interaction between inbreeding level of queen and workers in the evaluation (Table II), also a significiant queen effect was found. It has to be stressed that the individual columns in Figs. 2, 3 and 4 are based on different numbers of observations, which may give the impression of dissimilarities between the general tendency presented in Table II and the graphical presentation of special combinations of (particularly in the case of high) inbreeding level of queen and workers. This applies especially to the trait "swarming tendency" (Fig. 4) computed from a reduced data set only (Table I).

However, Fig. 4 indicates that the relationship between the level of inbreeding and swarming tendency is not linear, since the highest swarming tendency (lowest LSQ-means) occurs at medium (6.25\%$12.5 \%$ ) inbreeding of queens. Simpson (1958) suggested that swarming as well as supersedure is caused by a queen substance deficiency. Allen (1965) found weather and age of the queen influenced the production of queen cells and some evidence that older queens were more likely to be replaced than younger ones.

If the assumption of a relationship between inbreeding of queens and their pheromone production is correct, the differences between our results and the findings of Plass (1953) are reconcilable. Highly inbred queens (assumed to have very low pheromone production-like old queens) may entail supersedure, while a medium level of inbreeding (only reduced pheromone production) may promote swarming of the colony. Supersedure, discernible by extensive number of queen cells (Allen, 1965), is considered as a sign of little swarming tendency (Zander and Böttcher, 1979). This may explain the more favourable swarming tendency of colonies with highly inbred queens and the concomitant failure of the partial regression of swarming tendency of the colony on queen's inbreeding to reach significance (Table II). 
The increased swarming tendency of inbred workers is unexpected, because of the reduced vitality (Brückner, 1975) and (due to the mode of sex determination) smaller colony size. Insufficient hive space has usually been assumed to be a further cause of swarming (Simpson and Riedel, 1963). Not only did the absolute colony size affect swarming behaviour, but also worker concentration per unit (Free, 1968). Free (1968) found a dense worker concentration on the broodnest in small colonies and, possibly as a consequence of this, a tendency to swarm.

\section{Résumé - Effets de la consanguinité des reines et des ouvrières sur les ca- ractéristiques de la colonie d'abeilles.} On a adapté au cas particulier de l'abeille une méthode développée par Heijden et al. (1977) et Dempfle (1987) pour calculer les coefficients de consanguinité dans de grandes populations. La consanguinité des reines et des ouvrières de 5581 colonies, issues d'accouplement contrôlé, a été ainsi calculée. Sur plus de 30 ans la consanguinité des reines a augmenté de $0,15 \%$ et celle des ouvrières de $0,06 \%$ par an (Fig. 1). Le coefficient individuel de consanguinité le plus élevé a été de $44 \%$ chez les reines et de $45 \%$ chez les ouvrières. En appliquant la régression partielle des caractéristiques de la colonie sur la consanguinité de la reine et des ouvrières d'une colonie, on a pu quantifier les conséquences de la consanguinité sur ces caractéristiques pour les deux castes séparément.

La production miel et de cire est atteinte en premier lieu par la consanguinité des ouvrières, de 6 et $8 \%$ respectivement par $1 \%$ de consanguinité. Ces caractéristiques de la colonie ne sont touchées par la consanguinité de la reine que si les ouv- rières sont elles-mêmes fortement consanguines. Les ouvrières sont capables de compenser la dépression consanguine des reines, mais l'inverse n'est pas vrai (Fig. 1). La consanguinté des ouvrières rend la colonie plus calme et moins agressive, alors que la consanguinité des reines a l'effet inverse. La consanguinité des reines ou des ouvrières n'exerce aucune action sur le développement de la colonie au printemps (Tableau II).

La tendance à l'essaimage d'une colonie croît avec la consanguinité des ouvrières. Elle est par contre maximale avec des reines ayant une consanguinité moyenne. La modification du comportement de la colonie pourrait être due à une diminution de la production de phéromones par la reine, à une vitalité réduite et à une modification de la sensibilité des ouvrières aux phéromones. Des interactions significatives entre le niveau de consanguinité des reines et celui des ouvrières au sein d'une colonie ont été montrées pour la production de miel, pour l'agressivité durant l'ouverture des ruches et pour la tendance à l'essaimage.

Zusammenfassung - Einfluss der Inzucht von Königinnen und Arbeitsbienen auf die Volkseigenschaften bei der Honigbiene. Eine von Heijden et al. (1977) und Dempfle (1987) entwickelte Methode zur Berechnung von Inzuchtkoeffizienten in großen Populationen wurde den reproduktionsbiologischen Besonderheiten der Honigbiene angepaßt. Die Inzucht der Königinnen und der "Durchschnittsarbeiterinnen" von 5581 kontrolliert gepaarten Völkern konnte mit Hilfe dieser Methode berechnet werden. Bei den Königinnen errechnete sich eine Inzuchtsteigerung von $0,15 \%$ und bei den Arbeiterinnen von $0,06 \%$ pro Jahr (Abb. 1). Der 
höchste Inzuchtkoeffizient war bei einzelnen Königinnen $44 \%$ und bei einzelnen Arbeiterinnengruppen 45\%. Durch Anwendung der partiellen Regression der Volkseigenschaften auf die Inzucht von Königin und Arbeiterinnen eines Volkes konnten die Konsequenzen der Inzucht auf diese Volkseigenschaften für beide Kasten getrennt quantifiziert werden.

Der Honig- und Wachsertrag ist in erster Linie durch die Inzucht der Arbeiterinnen um $6 \%$ bzw. $8 \%$ je Prozent Inzucht beeinträchtigt. Eine Beeinflussung dieser Volkseigenschaften durch die Inzucht der Königin zeigt sich erst, wenn die Arbeiterinnen dieses Volkes selbst stark ingezüchtet sind. Inzuchtdepression der Königin ist bei den Produktionseigenschaften normalerweise durch heterozygote Arbeiterinnen kompensierbar. Nicht ingezüchtete Königinnen sind dagegen nicht in der Lage, Inzuchtfolgen der Arbeiterinnen auszugleichen (Abb. 1) Die Inzucht der Arbeiterinnen wirkt sich auf die Aggressivität und den Wabensitz eines Volkes positiv aus, während ingezüchtete Königinnen die gegenteilige Auswirkung auf die Volksreaktion haben. Bezüglich der Frühjahrsentwicklung eines Volkes konnte keine Beeinträchtigung durch die Inzucht beider Kasten nachgewiesen werden (Tab. II).

Die Schwarmneigung eines Volkes steigt mit steigender Inzucht der Arbeiterinnen. Bei Königinnen zeigt sich bei mittlerem Inzuchtniveau die ausgeprägteste Schwarmneigung. Als Ursachen des veränderten Volksverhaltens wurde eine Beeinträchtigung der Pheromonproduktion der Königin, reduzierte Vitalität und veränderte Pheromonsensibilität der Arbeiterinnen diskutiert. Interaktionen zwischen dem Inzuchtniveau von Königin und Arbeiterinnen innerhalb eines Volkes wurden für den Honigertrag, den Wabensitz und für die Schwarmneigung festgestellt.

\section{ACKNOWLEDGMENTS}

We wish to thank F. Tiesler (Landesverband für Bienenzucht Hannover and Weser-Ems), Professor Dr. J.H. Dustmann and Miss E. Englert (Niedersächisches Landesinstitut für Bienenzucht in Celle, F.R.G.), Dr V. Maul (Landesanstalt für Leistungsprüfungen in der TierzuchtAbteilung für Bienenzucht-Kirchhain, F.R.G.), Dr. H. Pechhacker (Höhere Bundesiehr- und Versuschsanstalt für Wein- und Obstbau mit Institut für Bienenkunde in Linz, Austria) and all beekeepers for providing the data. Financial support was provided by the Deutsche Forschungsgemeinschaft, Grant No. Pi 90-42.

\section{REFERENCES}

Allen M.D. (1965) The production of queen cups and queen cells in relation to the general development of honeybee colonies, and its connection with swarming and supersedure. J. Apic. Res. 4, 121-141

Bienefeld K. (1988a) Vererbung von Leistungseigenschaften bei der Honigbiene (Apis mellifica L.). Ph. D. Thesis, Technische Universität München-Weihenstephan, F.R.G.

Bienefeld K. (1988b) 30 Jahre CarnicaReinzucht-Überblick und Ergebnisse. Allg. Dtsche Imkerztg. 22, 221-226

Brückner D. (1975) Die Abhängigkeit der Temperaturregulierung von der genetischen Variabilität der Honigbiene (Apis mellifica). Apidologie 6, 361-380

Brückner D. (1980) Hoarding behaviour and life span of inbred, non-inbred and hybrid honeybees. J. Apic. Res. 19, 35-41

Cale G.H. \& Gowen J.W. (1956) Heterosis in the honey bee (Apis mellifera L.) Genetics 41, 292303

Chevalet C. \& Cornuet J.M. (1982) Etude théorique sur la sélection du caractère "production de miel" chez l'abeille. I. Modèle génétique et statistique. Apidologie 13, 39-65

Collins A.M., Rinderer T.E., Tucker K.W. \& Pesante D.G. (1987) Response to alarm phero- 
mone by European and Africanized honey bees. J. Apic. Res. 26, 217-223

Crewe R.M. (1982) Compositional variability: the key to the social signals produced by honey bee mandibular glands. In: The biology of social insects. (Breed M.D., Michener C.D., Evans H.E. eds.) Westview Press, Boulder

Dempfle L. (1987) Problems in the use of the relationship matrix in animal breeding. Int. Symp. Advances Stat. Methods Genet. Improvement Livest., Armidale, New South Wales, Australia, in press

Dickerson G.E. (1973) Inbreeding and heterosis in animals. Proc. Ann. Breed. Gen. Symp. in Honor of J.L. Lush, Champain, IL, ASAS and ADSA, pp. 54-77

Free J.B. (1968) Neue Entdeckungen über das Verhalten der Bienen, die gegebenenfalls Anwendung für die Bienenkultur haben. Apiacta 3, 1-6

Heijden E.Ter., Chesnais J.P. \& Hickman C.G. (1977) An efficient method of computing the numerator relationship matrix and its inverse with inbreeding for large sets of animals. Theor. Appl. Genet. 49, 237-241

Henderson C.R. (1976) A simple method for computing the inverse of a numerator relationship matrix used in prediction of breeding values. Biometrics 32, 69-83

Hoffmann I. (1961) Über die Arbeitsteilung in weiselrichtigen und weisellosen Kleinvölkern der Honigbiene. Z. Bienenforsch. 5, 267-279

Hoopingarner R. \& Farrar C.L. (1959) Genetic control of size in queen honey bees. J. Econ. Entomol. 52, 547-548

Kepena L. (1976) Lebensdauer durch Inbreeding und Outbreeding unter Laborbedingungen erzielter Bienen. In: Genetik, Selektion und Reproduktion bei der Honigbiene, Apimondia, Bucharest. pp. 56-59

Khischa W.D. (1976) Einfluss von Inzucht und Zwischenlinien-kreuzungen auf Merkmale und Eigenschaften der Bienen. In: Genetik, Selektion und Reproduktion bei der Honigbiene, Apimondia, Bucharest, pp. 60-68

Laidlaw H.H. (1974) Die Verwandtschaftsbeziehungen zwischen den Individuen eines Bienenvolkes. Apiacta 9, 49-52

Malécot G. (1948) Les Mathématiques de
I'Hérédité. Masson et Cie, Paris

Moritz R.F.A. (1982) Maternale Effekte bei der Honigbiene (Apis mellifera L.). Z. Tierzüchtg. Züchtungsbiol. 99, 139-148

Moritz R.F.A. (1986) The origin of inbreeding depression in honey bees. Bee World 67, 157. 163

Plass F. (1953) Inzuchtwirkung und Heterosiseffekt bei der Honigbiene. Schriftreihe des AID, Heft 66, Fortschritte in der Bienenzucht, pp. 4968

Polhemus M.S., Lush J.L.\& Rothenbuhler W.C. (1950) Mating systems in honey bees. J. Hered. 41, 151-154

Roberts W.C. (1961) Heterosis in the honey bee as shown by morphological characters in inbred and hybrid bees. Ann. Entomol. Soc. Am. 54, 878-882

Ruttner F. (1972) Technische Empfehlung zur Methodik der Leistungsprüfung von Bienenvölkern. Paarungskontrolle und Selektion bei der Honigbiene. Int. Symp. Apimondia, Lunz am See, Österreich, pp. 103-107

Simpson J. (1958) The factors which cause colonies of Apis mellifera to swarm. Insects Soc. 5, 77-95

Simpson J. \& Reidel I.B.M. (1963) The factor that causes swarming by honey bee colonies in small hives. J. Apic. Res. 2, 50-54

Tiesler F. (1988) Kooperative Organisationen der Zuchtarbeit. Allg. Dtsch. Imkerztg. 22, 333336

Velthuis H.H.W. (1977) The evolution of honey bee queen pheromones. Proc. VIII int. Congr. IUSSI, Wageningen, pp. 220-222

Woyke J. (1963) What happens to diploid drone larvae in a honey bee colony. J. Apic. Res. 2, 73-76

Woyke J. (1985) Instrumental insemination of honey bee queens in the development of bee keeping. World Anim. Rev. No. 56, 40-44

Zander E. \& Böttcher F.K. (1979) Haltung und Zucht der Biene. Eugen Ulmer Verlag, Stuttgart 